\title{
PENGARUH BUDAYA KERJA TERHADAP KINERJA KARYAWAN DI PT. BPR NUSAMBA KUBUTAMBAHAN
}

\author{
Komang Dyah Novi Anggeline ${ }^{1}$, Made Ary Meitriana ${ }^{2}$, I Nyoman Sujana ${ }^{3}$ \\ Jurusan Pendidikan Ekonomi \\ Universitas Pendidikan Ganesha \\ Singaraja, Indonesia
}

e-mail: novi.anggeline@gmail.com ${ }^{1}$ suianatbn@yahoo.com²

\begin{abstract}
Abstrak
Penelitian ini bertujuan untuk mengetahui budaya kerja yang diterapkan di PT. BPR Nusamba Kubutambahan dan pengaruh budaya kerja terhadap kinerja karyawan PT. BPR Nusamba Kubutambahan. Jenis penelitian ini merupakan penelitian kausal. Sampel penelitian ini adalah karyawan PT. BPR Nusamba Kubutambahan sebanyak 31 orang. Jenis data penelitian ini adalah data kuantitatif berupa skor jawaban kuesioner budaya kerja dan kinerja karyawan. Sumber data primer berupa skor jawaban kuesioner budaya kerja dan kinerja karyawan. Data dikumpulkan dengan metode kuesioner. Metode kuesioner digunakan untuk mengumpulkan data budaya kerja dan kinerja karyawan. Teknik analisis data menggunakan analisis regresi linier sederhana berbantuan program SPSS 25.0 for Windows. Hasil penelitian menunjukkan bahwa budaya kerja yang diterapkan sudah sangat baik dinyatakan oleh 26 orang (84\%) karyawan, budaya kerja yang diterapkan sudah baik dinyatakan oleh 2 orang $(6 \%)$, dan budaya kerja yang diterapkan sudah cukup dinyatakan oleh 3 orang $(10 \%)$ serta budaya kerja berpengaruh signifikan terhadap kinerja karyawan, yang ditunjukkan dengan nilai t hitung $=6,922>\mathrm{t}$ tabel $=2,045$.
\end{abstract}

Kata kunci: budaya kerja, kinerja karyawan.

\begin{abstract}
This research was aimed to identify the work culture applied in PT. BPR Nusamba Kubutambahan and the effect of work culture on the employees performance of PT. BPR Nusamba Kubutambahan. This research was causal research. The sample of this research were employees of PT. BPR Nusamba Kubutambahan as many as 31 people. The data type of this research was quantitative data in the form of answer score of work culture and employees performance questionnaire. Primary data source in the form of work culture and employees performance questionnaire answer score. The data collected by method of questionnaire. Questionnaires method used to collect data of work culture and employees performance. Data analysis technique using simple linear regression analysis assisted program SPSS 25.0 for Windows. The research results showed that the work culture applied was very well expressed by 26 people $(84 \%)$ employees, the work culture applied was well expressed by 2 people (6\%), and the work culture applied was enough expressed by 3 people $(10 \%)$ and work culture had a significant effect on employee performance, which was indicated by the value of $t$ test $=6.922>t$ table $=2.045$.
\end{abstract}

Keywords: work culture, employees performance.

\section{PENDAHULUAN}

Kinerja merupakan suatu potensi yang

harus dimiliki oleh setiap pegawai untuk melaksanakan setiap tugas dan tanggung jawab yang diberikan organisasi kepada pegawai. Dengan kinerja yang baik, maka setiap pegawai dapat menyelesaikan segala beban organisasi dengan efektif dan efesien sehingga masalah yang terjadi pada organisasi dapat teratasi dengan baik. 
Sebagaimana yang dikemukakan oleh (Rivai, 2005) kinerja karyawan adalah kesediaan seseorang atau kelompok orang untuk melakukan suatu kegiatan untuk pembedaan antar karyawan yang satu dengan yang lain. Kinerja merupakan suatu fungsi kemampuan pekerja dalam menerima tujuan pekerja. Tingkat pecapaian tujuan dan interaksi antara tujuan dan kemampuan pekerja (Nawawi, 2006). Dengan definisi tersebut dapat dikatakan bahwa karyawan memegang peranan penting dalam menjalankan segalan aktivitas perusahaan agar dapat tumbuh berkembang mempertahankan kelangsungan hidup perusahaan. Suatu organisasi, baik pemerintah maupun swasta untuk mencapai tujuannya, harus melalui sarana dalam bentuk organisasi yang digerakkan sekolompok orang yang berperan aktif sebagai pelaku dalam upaya mencapai tujuan perusahaan atau organisasi (Sedarmayanti, 2007:263).

Perspektif manajemen sumber daya manusia strategis yang paling mendasar adalah asumsi keberhasilan sebuah kinerja perusahaan yang dipengaruhi oleh tindakan dan peran manajemen sumber daya manusia yang dimiliki oleh perusahaan atau organisasi tersebut. Jadi sebaiknya apapun strategi yang dirancang oleh para manajer, tanpa didukung penuh oleh para rekan sekerja maupun bawahannya tentu tidak akan berguna maupun bermanfaat bagi perusahaan. Setiap organisasi didalam perusahaan tertentu selalu mempunyai tujuan dan menginginkan adanya suatu keberhasilan dalam usahanya. Suatu organisasi, baik pemerintah maupun swasta untuk mencapai tujuannya. Tanpa kemampuan yang baik dari karyawan, tujuan yang ditetapkan tidak akan pernah tercapai. Hal itu terjadi karena banyak karyawan tidak berusaha maksimal dalam pekerjaannya, sehingga target yang ditetapkan perusahaan tidak tercapai sebagai akibat dari kinerja karyawan yang tidak maksimal.

Kinerja merupakan suatu fungsi kemampuan pekerja dalam menerima tujuan pekerja. Tingkat pecapaian tujuan dan interaksi antara tujuan dan kemampuan pekerja (Nawawi, 2006). Dengan definisi tersebut dapat dikatakan bahwa karyawan memegang peranan penting dalam menjalankan segalan aktivitas perusahaan agar dapat tumbuh berkembang mempertahankan kelangsungan hidup perusahaan. Keutamaan budaya kerja merupakan pengendalian dan arah dalam membentuk sikap dan perilaku manusia yang melibatkan diri dari suatu kegiatan organisasi. Budaya kerja mempengaruhi produktivitas, kinerja komitmen, kepercayaan diri, dan perilaku etis. Budaya kerja memiliki tujuan untuk mengubah perilaku yang ada agar dapat meningkat kinerja perusaahaan (Warshina, 2011:4). Hal ini didukung pula oleh hasil penelitian Widodo (2013), yang menunjukkan budaya kerja berpengaruh secara positif dan signifikan terhadap kinerja karyawan."

Menurut Sedarmayanti (2007:260), "Kinerja terjemahan dari "performance" berarti hasil kerja yang dapat dicapai oleh seseorang atau sekelompok orang dalam suatu organisasi, sesuai dengan wewenang dan tanggung jawab masing-masing dalam rangka upaya mencapai tujuan organisasi bersangkutan secara legal, tidak melanggar hokum dan sesuai dengan norma maupun etika." Sedangkan Menurut Hariandjha (2002:24) kinerja merupakan hasil kerja yang dihasilkan oleh karyawan sesuai dengan peranannya dalam organisasi. Kinerja merupakan sesuatu yang sangat penting dalam usaha organisasi untuk mencapai tujuannya, sehingga sebagaian usaha secara kualitas dan kuantitas yang dicapai seorang pegawai dalam melaksanakan tugasnya sesuai dengan tanggung jawab yang diberikan kepadanya (Mangkunegara, 2006). Selain itu Menurut Wibowo (2010) kinerja memiliki makna yang lebih luas bukan hanya sebatas hasil kerja tetapi termasuk bagaimana proses kerja berlangsung. Pengertian kinerja tidak lain merupakan outcome yang dihasilakan dari fungsi suatu pekerjaan atau kegiatan tertentu seama periode waktu tertentu. Pendapat lainnya juga diungkapkan oleh Suswardji dkk. (2012:5), "Kinerja adalah hasil atau tingkat keberhasilan, kemampuan, usaha dan tanggung jawab seseorang dalam melaksanakan pekerjaan dan menyempurnakan hasil pekerjaan 
sesuia fungsi target atau sasaran serta kriteria yang ditetapkan mencakup kualitas dan kuantitas hasil pekerjaan, waktu penyelesaian pekerjaan serta kerjasama secara tim dalam melakukan pekerjaan."

Husnan (2002:126) yang menetapkan ukuran kinerja berdasarkan empat dimensi dengan interprestasi, yaitu kualitas kerja meliputi ketepatan waktu dan ketelitian karyawan, kuantitas kerja meliputi memenuhi standar kerja serta pekerjaan rutin terlaksana dengan cepat, tingkat kehandalan meliputi inisiatif, rajin dan kemampuan dalam bekerja, dan sikap indikatornya meliputi loyalitas dan tanggung jawab karyawan serta kerja sama dalam tim.

Tercapainya tujuan perusahaan dipengaruhi oleh beberapa faktor dari kinerja karyawan dalam perusahaan. Menurut Mangkunegara (2006) ada beberapa faktor yang mempengaruhi kinerja karyawan adalah lingkungan kerja, kelengkapan kerja, budaya kerja, motivasi, kemampuan pegawai, struktur organisasi, kepemimpinan dan sebagainya. Kinerja karyawan merupakan hasil kerja yang dapat capai oleh seseorang atau sekelompok orang dalam suatu organisasi, sesuai dengan wewenang dan tanggung jawab masing-masing dalam rangka upaya mencapai tujuan berkaitan kuat terhadap tujuan-tujuan strategi organisasi.

Munafiah (2011) menyatakan bahwa terdapat dua faktor yang mempengaruhi kinerja karyawan dalam perusahaan, yaitu faktor internal dan faktor eksternal. Dalam penelitian ini, faktor yang akan dikaji adalah dari sisi eksternal dalam budaya kerja dan intensitas persaingan. Hessel (2007) menyatakan bahwa unsur manusia penting, karena manusia selalu berperan aktif dan dominan dalam setiap organisasi. Manusia, adalah perencana, pelaku sekaligus penentu terwujudnya tujuan perusahaan. Dengan demikian sumber daya manusia dituntut untuk memiliki kemampuan dalam menjalankan tugas dan tanggung jawab untuk berpartisipasi dalam kegiatan perusahaan secara efektif dan efisien.

Menurut Mangkunegara (2006), kinerja karyawan dapat dinilai dengan aspek yang terdiri dari aspek kuantitatif dan kualitatif. Untuk menilai kinerja karyawan Aspek kuantitaitf terdiri dari proses kerja dan kondisi pekerjaan; waktu yang dipergunakan atau lamanya melaksanakan pekerjaan; jumlah kesalahan dalam melaksanakan pekerjaannya; jumlah dan jenis pemberian pelayanan dalam bekerja. Aspek kualitatif terdiri dari ketepatan kerja dan kualitas pekerjaan; tingkat kemampuan dalam pekerjaan; kemampuan dalam menganalisa data/informasi, kemampuan/ kegagalan dalam menggunakan peralatan; kemampuan mengevaluasi (keluhan masyarakat).

Agar kinerja karyawan sesuai dengan standar pekerjaan yang terdiri dari aspek kuantiatif dan aspek kualitatif, maka pemimpin perusahaan menegakkan aturanaturan didalam persoalan dan senantiasa memberikan perhatian dan pengawasan. Secara moral, perusahaan memberikan pengawasan terhadap karyawan dan material berupa pemberian kompensasi, menyediakan fasilitas ibadah dan tempat kerja yang nyaman. Kenyataan di lapangan ada banyak karyawan yang tidak mematuhi aturan-aturan yang dibuat perusahaan misalnya : masih ada karyawan yang tidak mematuhi kode etik yang ada di perusahaan, masih ada karyawan yang tidak bertanggung jawab dalam menyelesaikan tugasnya dan masih ada karyawan yang tidak tepat waktu dalam bekerja.

Langkah konkrit yang telah dilakukan perusahaan untuk menyelesaikan permasalahan tersebut yaitu melalui budaya kerja yang terkait dengan sumber daya manusia. Dimana sumber daya manusia memegang peranan yang sangat Penting dalam proses transformasi budaya yang terjadi di perusahaan dalam upaya pencapaian hasil kinerja karyawan yang optimal. Aspek budaya kerja adalah nilai yang menjadi pedoman sumber daya manusia untuk menghadapi permasalahan eksternal dan usaha penyesuaian intergritas ke dalam perusahaan, sehingga anggota organisasi mampu memahami nilai-nilai yang ada dan bagaimana mereka harus bertindak atau berprilaku (Susanto, 2007). dalam rangka menghasilkan output baik produk ataupun jasa perusahaan telah 
membentuk suatu upaya stratergis dalam membenahi kinerja karyawannya. Oleh sebab itu diperlukan adanya suatu perubahan atmosfir kerja berupa perubahan paradigma atau cara pandang, pola pikir, dan cara bertindak dalam menjalankan kegiatan operasional perusahaan. Dengan demikian, program transformasi kultural disuatu perusahaan dapat berjalan dengan baik. Adapun sutau perusahaan yang telah menjalankan hal tersebut akan memiliki ciriciri perubahan yang bersifat sangat mendasar, strategis, dan menyeluruh sehingga tujuan yang telah ditetapkan dalam bentuk visi dan misi dapat terlaksana dengan optimal.

Budaya kerja diturunkan oleh budaya organisasi. Triguno (2004:1) berpendapat bahwa "Budaya kerja merupakan suatu falsafah yang didasari oleh pandangan hidup sebagai nilai-nilai yang menjadi sifat, kebiasaan, dan kekuatan pendorong, membudaya dalam kehidupan suatu kelompok masyarakat yang terwujud sebagai "kerja atau bekerja". Sedangkan Sugiarto (2007:3) berpendapat bahwa "Budaya kerja adalah nilai dominan yang disebarluaskan didalam organisasi perusahaan dan diacu sebagai filosofi kerja karyawan serta memberikan disiplin kerja yang tinggi." Selanjutnya Herliany (2008:5) mengemukakan bahwa "Budaya kerja adalah suatu falsafah yang didasari pandangan hidup sebagai nilai-nilai yang menjadi sifat, kebiasaan dan juga pendorong yang dibudayakan dalam suatu kelompok dan tercermin dalam sikap menjadi perilaku, cita-cita, pendapat, pandangan serta tindakan yang terwujud sebagai kerja." Menurut Moeljono (2005) Budaya kerja pada umumnya merupakan pernyataan filosofi, dapat difungsikan sebagai tuntutan yang mengikat pada karyawan karena dapat diformulasikan secara formal dalam berbagai peraturan dan ketentuan perusahaan. Secara individu mauapun kelompok seseorang tidak akan terlepas dari budaya yang ada dalam perusahaan. Pada umumnya mereka akan dipengaruhi oleh keanekaragaman sumber daya yang ada sebagai stimulus sehingga seseorang dalam perusahaan mempunyai perilaku yang spesifik bila dibandingkan dengan kelompok organisasi atau perusahaannya.

Dari beberapa pendapat ahli dapat disimpulkan bahwa budaya kerja adalah suatu falsafah yang didasari oleh pandangan hidup sebagai nilai-nilai yang menjadi sifat, kebiasaan, dan kekuatan pendorong, membudaya dalam kehidupan suatu kelompok masyarakat yang terwujud "kerja atau bekerja". Budaya kerja memiliki tujuan utama dalam pelaksanaan kegiatan operasional perusahaan yaitu mengubah sikap dan juga perilaku SDM, sehingga pada gilirannya dapat meningkatkan kinerja dan sekaligus sebagai upaya strategis didalam menghadapi berbagai tantangan bisnis dimasa yang akan datang.

Menurut Moeljono (2013), dimensi yang digunakan untuk mengukur budaya kerja adalah sebagai berikut. Pertama, integritas adalah bertindak konsisten sesuai dengan nilai-nilai dan kebijakan organisasi serta kode etik profesi dalam melaksanakan tugas dan pekerjaannya dalam perusahaan. Indikatornya yaitu: konsisten tindakan dengan nilai, dan tindakan dengan kode etik profesi. Kedua, professionalisme merupakan tingkat pendidikan formal dan latihan-latihan khusus yang harus dimiliki karyawan untuk suatu posisi jabatan tertentu. Karyawan mampu menyelesaikan pekerjaannya secara efektif dan efesien. Jika untuk menduduki sebuah jabatan dalam organisasi seorang karyawan diharuskan memiliki pendidikan tertentu dan mempunyai pengalaman pelatihan yang cukup lama maka organisasi tersebut adalah organisasi professional. Indikatornya yaitu: efektif, efesien, dan disiplin. Ketiga, kepuasan adalah memenuhi kebutuhan dengan memberikan pelayanan yang terbaik, dengan tetap memperhatikan kepentingan perusahaan, SDM yang terampil, ramah dan senang melayani, serta teknologi unggul. Indikatornya: memberikan pelayanan yang baik, ramah, dan tekonologi unggul. Keempat, keteladanan merupakan perilaku dalam bekerja keras dan cerdas, dan membangun hubungan vertikan dan horizontal yang harmonis merupakan contoh-contoh perilaku sifat terpuji dari seseorang. Indikatornya yaitu: bekerja keras, bertindak adil dan bersikap 
tegas.

PT. BPR Nusamba Kubutambahan merupakan bank yang melaksanakan kegiatan usaha secara konvesional atau berdasarkan prinsip syariah dalam kegiatannya tidak memberikan jasa dalam lalu lintas pembayaran. Kegiatan utama usaha BPR tersebut ditujukan untuk melayani usaha-usaha kecil dan masyarakat dipedesaan. Adapun permasalahan yang ada di PT. BPR Nusamba Kubutambahan, yaitu sulit berkembangnya suatu usaha dalam BPR Nusamba sehingga terkesan beroperasi ala kadarnya sehingga menurunkan kepercayaan nasabah dan sulit merealisasikan peran ikut serta untuk menunjang pertumbuhan perekonomian daerah.

Bentuk hukum BPR dapat berupa perseroan terbatas, perusahaan daerah, atau koperasi. Hasil positif yang diperoleh PT. BPR Nusamba Kubutambahan. yang di duga dari pemegang budaya kerja yang baik. Pengaruh budaya kerja yang baik di PT. BPR Nusamba Kubutambahan., dapat digunakan dalam penyelesaian permasalahan internal dan eksternal perusahaan, sehingga budaya kerja terhadap peningkatan mutu kinerja para karyawan. Dengan demikian, melihat pentingnya peranan budaya kerja terhadap peningkatan kinerja karyawan dalam suatu perusahaan, maka penulis terdorong untuk meneliti tentang "Pengaruh Budaya Kerja Terhadap Kinerja Karyawan di PT. BPR Nusamba Kubutambahan."

\section{METODE}

Penelitian ini merupakan jenis penelitian kausal. Menurut Sugiyono (2012:56), "desain penelitian kausal adalah hubungan yang bersifat sebab akibat, variabel bebas merupakan variabel yang mempengaruhi dan variabel terikat merupakan variabel yang dipengaruhi". Adapun variabel-variabel yang digunakan dalam penelitian ini adalah budaya kerja $(X)$ dan kinerja karyawan (Y).

Populasi penelitian ini adalah karyawan PT. BPR Nusamba Kubutambahan. sebanyak 31 orang. Apabila populasi kurang dari 100 orang, maka sebaiknya semua dijadikan sebagai sasaran penelitian. Oleh karena itu, penelitian ini merupakan penelitian populasi atau penelitian sampel jenuh, yang artinya semua populasi dijadikan sebagai sampel penelitian. Populasi penelitian ini adalah 31 orang karyawan, sehingga sampel dari penelitian ini juga berjumlah 31 orang karyawan.

Jenis data yang digunakan dalam penelitian ini adalah data kuantitatif berupa skor jawaban kuesioner dari responden mengenai budaya kerja dan kinerja karyawan PT. BPR Nusamba Kubutambahan. Sumber data dalam penelitian ini adalah terdiri dari data primer. Data primer dalam penelitian ini berupa skor jawaban responden yang diperoleh melalui pengisian kuesioner mengenai budaya kerja dan kinerja karyawan PT. BPR Nusamba Kubutambahan.

Adapun metode pengumpulan data yang digunakan dalam penelitian ini adalah kuesioner. Kuesioner merupakan metode pengumpulan data untuk mendapatkan data tentang budaya kerja dan kinerja karyawan yang dilakukan dengan memberikan pernyataan kepada responden untuk dijawab. Data yang telah dikumpulkan digunakan sistem skor, dimana jawaban pertanyaan diberi skor dengan menggunakan skala likert. Skala likert merupakan skala yang digunakan untuk mengukur, sikap, pendapat, dan persepsi seseorang atau sekelompok orang tentang fenomena sosial (Sugiyono, 2012). Setiap pernyataan disediakan lima alternatif jawaban, yaitu apabila jawaban sangat setuju diberi skor 5, apabila jawaban setuju diberi skor 4, apabila jawaban kurang setuju sesuai diberi skor 3, apabila jawaban tidak setuju diberi skor 2, dan apabila jawaban sangat tidak setuju diberi skor 1 .

Kuesioner sebagai instrumen pengumpulan data terlebih dahulu harus diuji tingkat validitas dan reliabilitasnya. Untuk menguji tingkat validitas dan reliabilitas instrumen penelitian akan diujikan kepada 30 responden. Validitas adalah untuk melihat kecermatan alat ukur, yaitu mengukur apa yang akan diukur. Dalam penelitian ini, suatu kuesioner dinyatakan valid, jika pertanyaan maupun 
pernyataan pada kuesioner mampu untuk mengungkapkan sesuatu yang akan diukur oleh kuesioner tersebut. Pengujian validitas dalam penelitian ini dilakukan dengan menggunakan Person Correlation. Kriteria keputusan valid kuesioner dinyatakan apabila nilai $r_{\text {hitung }}$ lebih besar dari $r_{\text {tabel. }}$. Reliabilitas berkaitan dengan keterandalan suatu indikator. Informasi yang ada pada indikator ini tidak berubah-ubah, atau bisa disebut dengan kosisten. Uji reabilitas dilakukan untuk menguji apakah jawaban dari responden konsisiten. Suatu angket dikatakan reliable jika jawaban seseorang terhadap pertanyaan adalah konsisten atau stabil dari waktu ke waktu.Pengujian realibilitas dalam penelitian ini dilakukan dengan menggunakan Alpha Cronbach. Suatu instrumen dikatakan reliabel jika memiliki nilai Alpha Cronbach >0,60. Hasil uji validitas menunjukkan bahwa nilai $r_{\text {hitung }}$ pada kuesioner budaya kerja 17 item lebih besar dari $r_{\text {tabel }}=0,361$ sehingga 17 item pernyataan dinyatakan valid dan 5 item pernyataan dinyatakan tidak valid. Nilai $\mathrm{r}_{\text {hitung }}$ pada kuesioner kinerja karyawan 16 item lebih besar dari $r_{\text {tabel }}=0,361$ sehingga 16 item pernyataan dinyatakan valid dan 4 item pernyataan dinyatakan tidak valid. Hasil uji reliabilitas pada tabel menunjukan bahwa semua variabel memiliki Alpha Cronbach lebih besar dari 0,60. Jadi, dapat disimpulkan bahwa kuesioner budaya kerja dan kinerja karyawan adalah reliabel.

Analisis data yang digunakan dalam penelitian ini adalah analisis deskriptif, uji t, dan analisis regresi linier sederhana. Analisis deskriptif dilakukan untuk mengetahui budaya kerja yang di terapkan di PT. BPR Nusamba Kubutambahan. Kriteria penggolongan disusun berdasarkan skor rata-rata dan presentase skor rata-rata variabel budaya kerja dikonversikan terhadap kriteria mean ideal (Mi) dan standar deviasi ideal sebagai berikut (SDi) (Koyan, 2012).

$M_{i}+1,5 S D_{i} \leq M \leq M_{i}+3,0 S D_{i}$

$M_{i}+0,5 S D i \leq M<M i+1,5 S D_{i}$

$\mathrm{M}_{\mathrm{i}}-0,5 \mathrm{SDi} \leq \mathrm{M}<\mathrm{Mi}+0,5 \mathrm{SD}_{\mathrm{i}}$

$M_{i}-1,5 S D_{i} \leq M<M_{i}-0,5 S D_{i}$

$M_{i}-3,0 S D_{i} \leq M<M_{i}-1,5 S D_{i}$

Keterangan:

$\mathrm{M}$ = Skor budaya kerja

$M_{i}=$ Rata-rata ideal $=1 / 2$ (skor maksimal ideal + skor minimal ideal)

$\mathrm{SD}_{\mathrm{i}}=$ Standar deviasi ideal $=1 / 6$ (skor maksimal ideal - skor minimal ideal) Hasil yang diperoleh melalui kuesioner budaya kerja dipresentasikan dengan skor maksimal ideal $17 \times 5=85$ dan skor minimal ideal $17 \times 1=17$, Mean ideal $(\mathrm{Mi})$ adalah sebesar $1 / 2 \times(85+17)=$ 51. Standar deviasi ideal (SDi) sebesar $1 / 6$ $x(85-17)=34 / 3$. Jadi, dapat ditentukan kategori budaya kerja melalui kriteria seperti tampak pada tabel 1.

Tabel 1. Kriteria Penggolongan Budaya Kerja

\begin{tabular}{ccc}
\cline { 2 - 3 } No. & Kriteria & Kategori \\
\cline { 2 - 3 } 1 & $68 \leq \mathrm{M} \leq 85$ & Sangat Baik \\
2 & $56,67 \leq \mathrm{M}<68$ & Baik \\
3 & $45,33 \leq \mathrm{M}<56,67$ & Cukup \\
4 & $34 \leq \mathrm{M}<45,33$ & Kurang \\
5 & $17 \leq \mathrm{M}<34$ & Sangat Kurang \\
\hline
\end{tabular}

Pengujian hipotesis secara parsial menggunakan uji t. Uji t dilakukan untuk melihat signifikansi pengaruh independen secara individu terhadap variabel dependen (Ghozali, 2011). Pengujian ini dilakukan dengan membandingkan $t$ hitung dengan $t$ tabel. Analisis regresi linier sederhana digunakan untuk mengetahui pengaruh antara variabel bebas terhadap variabel terikat (Dantes, 2012).
Sebelum dilakukan pengujian analisis regresi linear sederhana, maka dilakukan pengujian asumsi klasik berupa uji normalitas data dan uji linearitas. Uji normalitas data bertujuan untuk menguji apakah model dalam regresi variabel terikat dan variabel bebas keduanya mempunyai distribusi normal atau tidak (Ghozali, 2011). Uji normalitas residual dilakukan dengan menggunakan One Sample Kolmogorov- 
Smirnov Test dengan taraf signifikansi $5 \%$. Dasar pengambilan keputusan normal adalah jika nilai signifikansi $\geq 0,05$, maka data berdistribusi normal dan jika nilai signifikansi < 0,05, maka data tidak berdistribusi normal.

Uji linearitas digunakan untuk melihat apakah model regresi yang digunakan sudah benar atau tidak. Uji yang digunakan untuk menguji linearitas model regresi adalah uji Lagrange Multiplier (Ghozali, 2011). Uji ini bertujuan untuk mendapatkan nilai $c^{2}$ hitung $\left(n \times R^{2}\right)$. Kriteria pengujiannya adalah model regresi disebut linear jika nilai $c^{2}$ hitung lebih kecil dari nilai $c^{2}$ tabel.

\section{HASIL DAN PEMBAHASAN}

Berdasarkan hasil analisis jawaban karyawan PT. BPR Nusamba Kubutambahan. terhadap 17 item pernyataan kuesioner budaya kerja terungkap deskripsi budaya kerja dengan berpedoman pada kriteria penggolongan seperti pada tabel

Tabel 2. Deskripsi Data Budaya Kerja

\begin{tabular}{cccc}
\hline Kriteria & Kategori & Jumlah Karyawan (Orang) & Persentase (\%) \\
\hline $68 \leq \mathrm{M} \leq 85$ & Sangat Baik & 26 & 84 \\
$56,67 \leq \mathrm{M}<68$ & Baik & 2 & 6 \\
$45,33 \leq \mathrm{M}<56,67$ & Cukup & 3 & 10 \\
$34 \leq \mathrm{M}<45,33$ & Kurang & 0 & 0 \\
$17 \leq \mathrm{M}<34$ & Sangat Kurang & 0 & 0 \\
& Total & 31 & 100 \\
\hline
\end{tabular}

Berdasarkan tabel 2 dapat ditunjukkan bahwa sebanyak 26 orang (84\%) karyawan menyatakan bahwa budaya kerja yang diterapkan sudah sangat baik, sebanyak 2 orang $(6 \%)$ karyawan menyatakan bahwa budaya kerja yang diterapkan sudah baik, dan sebanyak 3 orang (10\%) karyawan menyatakan bahwa budaya kerja yang diterapkan cukup. Hal ini menunjukkan bahwa budaya kerja yang diterapkan pada PT. BPR Nusamba Kubutambahan sudah sangat baik.

Berdasarkan hasil analisis data menunjukkan bahwa secara parsial budaya kerja terhadap kinerja karyawan pada PT. BPR Nusamba Kubutambahan. dapat diketahui dengan menggunakan uji $t$. Perhitungan uji $\mathrm{t}$ menggunakan bantuan program SPSS 25.0 for Windows dan pengujian hipotesis dilakukan pada taraf signifikansi $5 \%$. Hasil uji t dapat dilihat pada tabel

Tabel 3. Hasil Uji t

\begin{tabular}{|c|c|c|c|c|c|}
\hline \multirow{2}{*}{\multicolumn{2}{|c|}{ Model }} & Unstandardized Coefficients & \multirow{2}{*}{$\begin{array}{c}\text { Standardized Coefficients } \\
\text { Beta }\end{array}$} & \multirow{2}{*}{$\mathrm{t}$} & \multirow{2}{*}{ Sig. } \\
\hline & & $\begin{array}{cc}\text { B } & \text { Std. Error } \\
\end{array}$ & & & \\
\hline 1 & $(\mathrm{Cc}$ & 5,740 & & 0,725 & 0,474 \\
\hline & Budaya kerja & 0,112 & 0,789 & 6,922 & 0,000 \\
\hline
\end{tabular}

a. Dependent Variable: Kinerja karyawan

Berdasarkan tabel 3, diperoleh nilai $\mathrm{t}$ hitung $=6,922>\mathrm{t}$ tabel $=2,045$, maka $\mathrm{H}_{0}$ ditolak dan $\mathrm{H}_{\mathrm{a}}$ diterima. Jadi, terdapat pengaruh yang signifikan antara budaya kerja terhadap kinerja karyawan pada PT. BPR Nusamba Kubutambahan.

Berdasarkan hasil analisis regresi linier sederhana, dapat diketahui persamaan garis regresi untuk mengetahui hubungan budaya kerja terhadap kinerja karyawan pada PT. BPR Nusamba Kubutambahan. dengan menggunakan analisis koefisien beta. Berdasarkan perhitungan koefisien beta pada tabel 3 , maka didapat hasil persamaan regresi sebagai berikut.

$\mathrm{Y}=4,162+0,774 \mathrm{X}$

Keterangan:

$\mathrm{Y}=$ kinerja karyawan

$\mathrm{X}=$ budaya kerja 
Berdasarkan model persamaan
regresi yang terbentuk, dapat diinterpretasikan hasil bahwa konstanta sebesar 4,162 menunjukan jika variabel budaya kerja $(X)$ bernilai konstan atau nol, maka variabel kinerja karyawan (Y) memiliki nilai positif sebesar 4,162. Selanjutnya, variabel budaya kerja $(X)$ memiliki koefisien positif sebesar 0,774 . Nilai koefisien regresi yang positif menunjukkan bahwa budaya kerja $(X)$ berpengaruh positif terhadap kinerja karyawan (Y). Hal ini menggambarkan bahwa peningkatan nilai budaya kerja $(X)$ sebesar satu satuan akan dapat meningkatkan kinerja karyawan (Y) sebesar nilai koefisien beta masing-masing variabel bebas dikalikan dengan besar kenaikan yang terjadi. Misalnya, setiap terjadi kenaikan budaya kerja $(X)$ sebesar 1 satuan, maka akan meningkatkan kinerja karyawan (Y) sebesar 0,774. Hal ini menunjukkan bahwa semakin baik budaya kerja, maka semakin tinggi kinerja karyawan pada PT. BPR Nusamba Kubutambahan. Sebaliknya, semakin buruk budaya kerja, maka semakin rendah kinerja karyawan pada PT. BPR Nusamba Kubutambahan.

Besar pengaruh budaya kerja terhadap kinerja karyawan pada PT. BPR Nusamba Kubutambahan dapat diketahui dari koefisien determinasi, yang ditunjukkan dengan nilai $R$ Square. Hasil analisis koefisien determinasi dapat disajikan pada tabel

Tabel 4. Hasil Koefisien Determinasi

\begin{tabular}{ccc}
\hline Model & $\mathrm{R}$ & $\mathrm{R}$ Square \\
\hline \hline 1 & 0,789 & 0,623 \\
Berdasarkan tabel & 4, diketahui bahwa
\end{tabular}
hasil perhitungan koefisien determinasi sebesar 0,623. Hal ini menunjukkan bahwa $62,3 \%$ variabel kinerja karyawan pada PT. BPR Nusamba Kubutambahan dipengaruhi oleh variabel budaya kerja, sedangkan $37,7 \%$ dipengaruhi oleh faktor lain yang tidak termasuk dalam penelitian ini.

Hasil penelitian menunjukkan bahwa terdapat pengaruh siginifikan antara budaya kerja dengan kinerja karyawan pada PT. BPR Nusamba Kubutambahan Persamaan regresi punya arah koefisien positif. Pengaruh positif menunjukkan bahwa hubungan budaya kerja dan kinerja karyawan adalah searah. Jika budaya kerja semakin baik, maka kinerja karyawan semakin tinggi.

Hasil penelitian ini didukung oleh teori yang dikemukan oleh Mangkunegara (2006), yang menyatakan bahwa salah satu faktor yang mempengaruhi keberhasilan kinerja adalah budaya kerja. Senada dengan itu, Hessel (2007) menyatakan bahwa salah satu faktor yang mempengaruhi kinerja adalah budaya perusahaan. Menurut Triguno (2004), budaya kerja memiliki tujuan untuk

\begin{tabular}{cc}
$\begin{array}{c}\text { Adjusted } \\
\text { R Square }\end{array}$ & $\begin{array}{c}\text { Std. Error } \\
\text { of the Estimate }\end{array}$ \\
\hline 0,610 & 5,674890
\end{tabular}

mengubah sikap dan juga perilaku sumber daya manusia yang ada agar dapat meningkatkan kinerja untuk menghadapi berbagai tantangan di masa yang akan datang.

Hasil penelitian ini juga didukung oleh hasil penelitian terdahulu yang dilakukan oleh Pradana (2012), yang menyatakan bahwa budaya kerja berpengaruh pada upaya peningkatan kinerja karyawan. Penelitian lain yang mendukung hasil penelitian ini dilakukan oleh Widodo (2013), yang menyatakan bahwa budaya kerja berpengaruh signifikan terhadap kinerja karyawan. Senada dengan itu, hasil penelitian oleh Silvia (2016) juga menemukan bahwa budaya kerja berpengaruh signifikan terhadap kinerja karyawan. Budaya kerja yang kaut akan menciptakan budaya perusahaan yang baik dan juga mencerminkan bahwa budaya tersebut telah memiliki akar yang kuat dimana telam mampu dijiwai serta diaktualisasikan dalam kegiatan sehari-hari. Hal tersebut seperti nilai-nilai apa saja yang patut dimiliki. Usaha penilaian terhadap nilai-nilai budaya kerja memiliki hubungan yang nyata dengan kinerja karyawan yang 
diharapkan mampu mendorong karyawan untuk melaksanakan tugas dan tanggung jawab pekerjaan secara baik atau benar.

Besar sumbangan pengaruh variabel budaya kerja terhadap kinerja karyawan ditunjukkan dengan koefisien determinasi sebesar 0,623. Hasil tersebut menunjukkan bahwa sebesar $62,3 \%$ kinerja karyawan dipengaruhi oleh variabel budaya kerja, sedangkan pengaruh dari variabel lain sebesar 37,7\%. Hasil penelitian ini menunjukkan bahwa terdapat variabel lain yang mempengaruhi kinerja karyawan. Secara teori, variabel lain tersebut yang dapat mempengaruhi kinerja karyawan menurut Mangkunegara (2006) adalah lingkungan kerja, kelengkapan kerja, motivasi kemampuan pegawai, struktur organisasi, dan kepemimpinan.

\section{SIMPULAN DAN SARAN}

Berdasarkan hasil penelitian dan pembahasan dapat ditarik simpulan sebagai berikut. Pertama, budaya kerja yang diterapkan sudah sangat baik dinyatakan oleh 26 orang (84\%) karyawan, budaya kerja yang diterapkan sudah baik dinyatakan oleh 2 orang (6\%), dan budaya kerja yang diterapkan sudah cukup dinyatakan oleh 3 orang (10\%). Kedua, budaya kerja berpengaruh positif dan signifikan terhadap kinerja karyawan pada PT. BPR Nusamba Kubutambahan, yang ditunjukkan dengan koefisien regresi yang positif 0,774 dengan nilai $t_{\text {hitung }}=6,922>$ $t_{\text {tabel }}=2,045$.

Berdasarkan hasil, pembahasan, dan simpulan, maka dapat diajukan saran sebagai berikut. Pertama, bagi pihak manajemen PT. BPR Nusamba Kubutambahan disarankan agar mewujudkan budaya kerja perusahaan yang kondusif dalam rangka mewujudkan kinerja karyawan yang optimal. Salah satu caranya adalah pada saat dilakukan rapat atau kegiatan briefing (pengarahan) yang dilakukan sebelum memulai karyawan mulai bekerja, pimpinan atau manajemen selalu memberikan arahan-arahan tentang menaati peraturan perusahaan sehingga integritas, profesionalisme, dan kepuasan kerja yang dimiliki karyawan semakin baik serta pimpinan selalu dapat menunjukkan keteladanan kepada karyawan pada saat kegiatan pengarahan tersebut. Hal ini diharapkan dapat mewujudkan budaya kerja yang mendukung bagi peningkatan kinerja karyawan. Kedua, bagi peneliti selanjutnya yang tertarik untuk mengkaji aspek yang serupa mengenai pengaruh budaya kerja terhadap kinerja karyawan diharapkan untuk mengembangkan penelitian ini dengan menggunakan populasi dan sampel yang lebih luas, tidak hanya di PT. BPR, tetapi juga di Bank Perkreditan Rakyat lainnya agar hasil penelitian lebih teruji keandalannya.

\section{DAFTAR PUSTAKA}

Dantes, Nyoman. 2012. Metode Penelitian. Yogyakarta: Andi Offset.

Ghozali, Imam. 2011. Aplikasi Analisis Multivariate dengan Program SPSS. Semarang: Badan Penerbit Universitas Diponegoro.

Hariandja, Marriot. 2002. Manajemen Sumber Daya Manusia. Jakarta: PT. Grasindo.

Herliany. 2008 Manajemen Sumber Daya Manusia Perusahaan. Bandung: PT Remaja Rosdakarya.

Hessel, Nogi S. Tangkilisan. 2002. Menejemen SDM Birokrasi Publik: Strategi Keunggulan Pelayanan Publik. Yogyakarta: YPAPI.

Husnan, Suad. 2002. Manajemen Keuangan Teori dan Praktek. Yogyakarta: Badan Penerbit Gajah Mada.

Koyan, I Wayan. 2012. Statistik Pendidikan Teknik Analisis Data Kuantitatif. Singaraja: Universitas Pendidikan Ganesha.

Mangkunegara, A. A. Anwar Prabu. 2006. Perilaku dan Budaya Organisasi. Bandung: PT. Rafika Aditama.

Moeljono, Djokosantoso. 2005. Budaya Organisasi dalam Tantangan. Jakarta: PT. Elex Media Komputindo.

Munafiah, Siti. 2011. Pengaruh Kompensasi dan Supervisi terhadap Kinerja Karyawan (Studi Kasus pada PT. 
Industri Sandang Nusantara Unit Patal Secang). Skripsi tidak diterbitkan. Yogyakarta: Universitas Negeri Yogyakarta.

Nawawi, Hadari. 2006. Evaluasi dan Manajemen Kinerja di Lingkungan Perusahaan dan Industri. Yogyakarta: Gadjah Mada University Press.

Pradana, RM. Gardhika Riza. 2012. Pengaruh Budaya Kerja Terhadap Kinerja Karyawan di Koperasi Karyawan Redrying Bojonegoro (Kareb). Skripsi tidak diterbitkan. Malang: Universitas Brawijaya.

Rivai, Veithzal. 2005. Manajemen Sumber Daya Manusia Untuk Perusahaan Dari Teori Ke Praktik. Jakarta: PT. Raja Grafindo Persada.

Sedarmayanti. 2007. Sumber Daya Manusia dan Produktivitas Kerja. Bandung: Mandar Maju.

Silvia. 2016. Pengaruh Kompetensi dan Budaya Kerja Terhadap Kinerja Karyawan. e-Journal Bisma Universitas Pendidikan Ganesha Jurusan Manajemen, 4(1), 1-9.

Sugiarto. 2007. Pengaruh Kepemimpinan, Disiplin, dan Budaya Kerja Terhadap Kepuasan Kerja Karyawan PT. Primatexco Indonesia. Jurnal Ekonomi dan Bisnis, 5(1), 1-16.

Sugiyono. 2012. Metode Penelitian Kuantitatif Kualitatif dan $R \& D$. Bandung: Alfabeta.

Susanto, A. B. 2007. Budaya Perusahaan: Manajemen dan Persaingan Bisnis. Jakarta: PT. Gramedia.

Suswardji, E., Hasbullah, R., dan Albatross, E. 2012. Hubungan Kompetensi dan Disiplin Kerja Terhadap Kinerja Tenaga Kependidikan Universitas Singaperbangsa Karawang. Jurnal Manajemen, 10(1), 955-979.

Triguno. 2004. Budaya Kerja: Menciptakan Lingkungan Yang Kondusif Untuk Meningkatkan Produktifitas Kerja. Jakarta: PT. Golden Trayon Press.
Warshina, Jaka. 2011. Budaya Kerja dan Kerjasama Tim. Jakarta: PT. Raja Grafindo Persada.

Wibowo. 2012. Manajemen Kinerja. Jakarta: PT. Raja Grafindo Persada.

Widodo. 2013. Analisis Pengaruh Antara Faktor Pendidikan, Motivasi dan Budaya Kerja Terhadap Kinerja Pegawai Dalam Pelayanan Publik Badan Pelayanan Perijinan Terpadu Kota Pontianak. Jurnal Manajemen dan Bisnis, 12(3), 1-20. 